\title{
ORGANS FOR SALE
}

\section{Bioethics, Neoliberalism, and Public Moral Deliberation}

Organs for Sale is a study of the bioethical question of how to increase human organ supply. But it is also an inquiry into public moral deliberation and the relationship between economic worth and the value systems of a society. Looking closely at human organ procurement debates, the author offers a critique of neoliberalism in bioethics and asks what kind of society we truly want.

While society has shown concern over debates surrounding organ procurement, a better understanding of the rhetoric of advocates and philosophical underpinnings of the debate might indeed improve our public moral deliberation in general and organ policy more specifically. Examining public arguments, this book uses a range of source material, from medical journals to congressional hearings to newspaper op-eds, to provide the most up-to-date and thorough analysis of the topic. Organs for Sale posits that deciding together on the limits of markets, and on what is and ought to be for sale, sheds light on the moral fibre of our society and what it needs to thrive.

RYAN GILLESPIE is a lecturer in the Study of Religion program at University of California, Los Angeles. 



\section{Organs for Sale}

Bioethics, Neoliberalism, and

Public Moral Deliberation

RYAN GILLESPIE

UNIVERSITY OF TORONTO PRESS

Toronto Buffalo London 
(C) University of Toronto Press 2021

Toronto Buffalo London

utorontopress.com

Printed in the U.S.A.

ISBN 978-1-4875-0603-2 (cloth) ISBN 978-1-4875-3316-8 (EPUB)

ISBN 978-1-4875-2405-0 (paper) ISBN 978-1-4875-3315-1 (PDF)

\section{Library and Archives Canada Cataloguing in Publication}

Title: Organs for sale : bioethics, neoliberalism, and public moral deliberation / Ryan Gillespie.

Names: Gillespie, Ryan, 1982- author.

Description: Includes bibliographical references and index.

Identifiers: Canadiana (print) 20200278940 | Canadiana (ebook) 20200278967 |

ISBN 9781487506032 (hardcover) | ISBN 9781487524050 (softcover) |

ISBN 9781487533168 (EPUB) | ISBN 9781487533151 (PDF)

Subjects: LCSH: Donation of organs, tissues, etc - Moral and ethical aspects. |

LCSH: Bioethics. | LCSH: Medical ethics.

Classification: LCC RD129.5 .G55 2020 | DDC 174.2/97954—dc23

University of Toronto Press acknowledges the financial assistance to its publishing program of the Canada Council for the Arts and the Ontario Arts Council, an agency of the Government of Ontario.

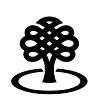

Canada Council for the Arts

Funded by the Financé par le Government gouvernement of Canada du Canada

\section{Conseil des Arts} du Canada

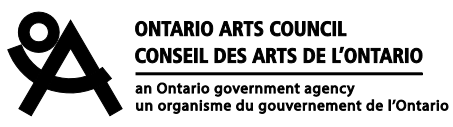

